\title{
腹壁破裂其他各種ノ畸形キ伴へル一胎兒二就テ
}

\section{日本醫科大學病理學数堂（指導 福士敉授）}

\author{
研究生 乫 唯稔
}

(昭利 16 年 5 月 24 日受理)

(本例八第 29 回日本病理學會二示部セルモノナリ)

\section{-[丙容抄錄]}

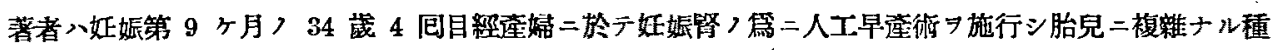

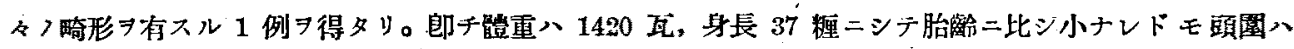
29 框

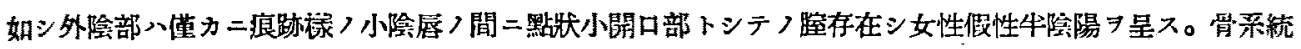

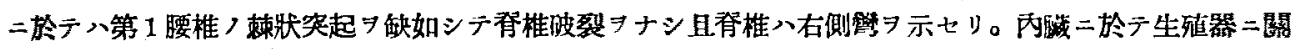

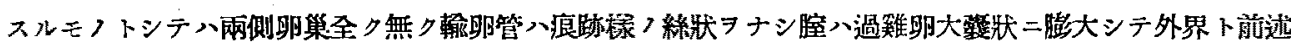

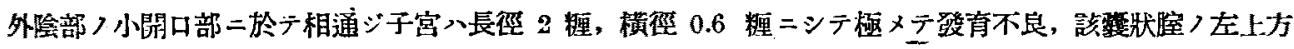

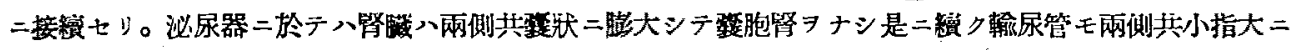

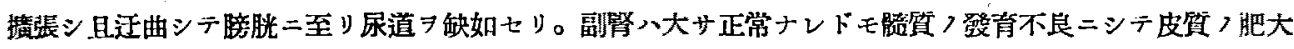

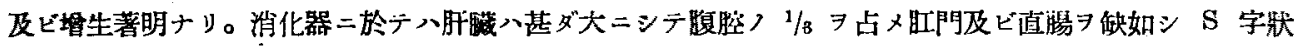
部二於テ盲端ニ終レリ。腦神經系統ニ於テハ大腦フ主要腦清既ニ具備セラレタルモ不規則ニシテ且渝っ第

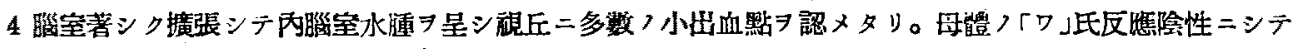

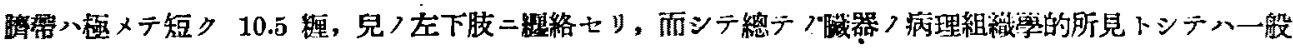

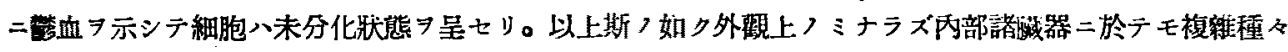
ニシテ而モ高度ナル畸形八稀有ナルモノ二虏ス。

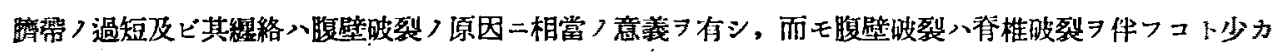
ラズシテ春椎繁曲モ亦腹壁皮裂二因果關倸ヨ有スルモノ下思惟ス。

[目次]

第 1 章 栯言

第2 章 實擥例

1) 臨床的事項

3) 剖检的所見

2) 畃眼的外部所見

4) 租綫學的所見

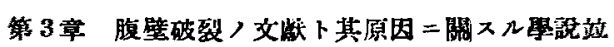
其考案

第4章宽略例所見卜腹壁破型，原因二就テ、考 案
1）短腈带及艘絡

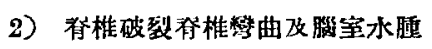

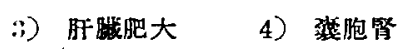

5) 羊水過多病

第 5 章 女性假性牛除陽

第6 章 最近;一般畸形發生諭

第 7 章 結諭交能

\section{第1章 緒 亩}

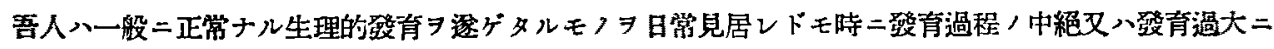

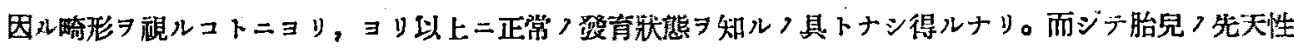

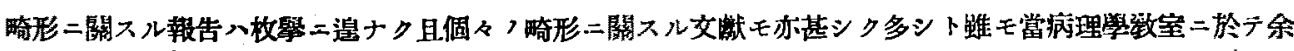

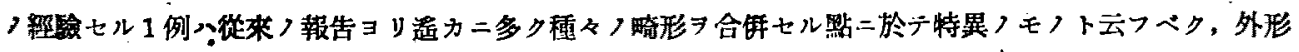




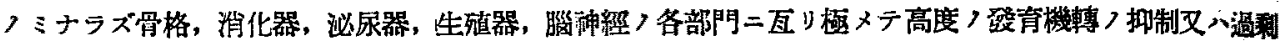
习發見シ得タリ。

这二其剖檢所見卜共二病理組織學的檢索习記載シ脌七う從來諸家二伐り述ベラレタル知見卜余フ見解， 一端ヨ述ペントス。

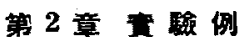

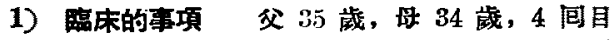

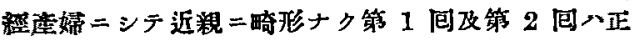

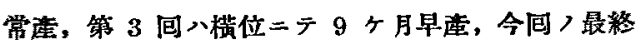
月絰八昭利 13 年 6 月 3 日ヨり.5日間ニシテ同月

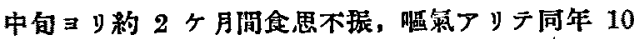
月 $\exists y$ 胎動 7 感 $x^{\circ}$ 。昭和 14 年 $1^{*}$ 月 21 日子宫底既

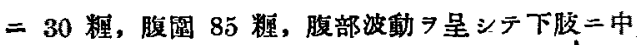

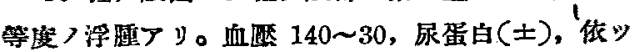

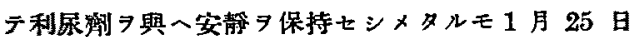

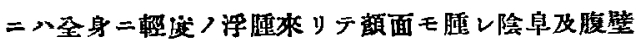

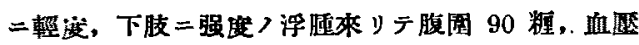
160 75 二上昇シ尿蛋白（サ）トナレリ。依ッテ檼

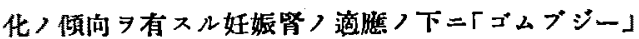
二本插入シ「アトニン日分割注射 3 回习施行せル 二竝早朝單整位二テ畸形兒习媸出ス。兒八第 2 健假 死ニシテ心音アリタルモ嗙泣セズシテ間モナク情死

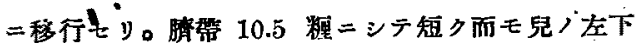

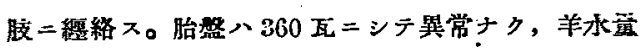

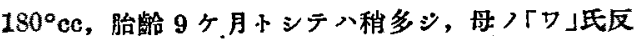
礁改ビ村田反然共二除性。

2) 内眼的外部所見 胎重 1420 瓦, 身長 37 精

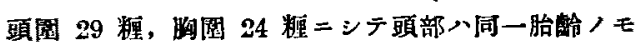

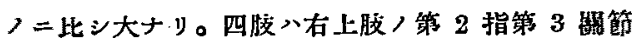
二於テ中断シ左上肢第 3 指モ第 3 關節 $コ$ 先方無 ク，右下肢八㸓化ナキモ左下肢》足關節ノ少シク上

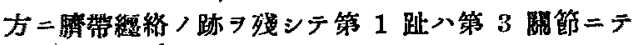
中数シ第 2 及策 3 趾入其先端二於テ相澺着セり。

腹部二於テ著シク特畏ナル所見トシテ長廿 3.5 糢

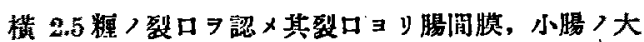

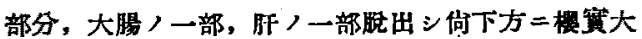

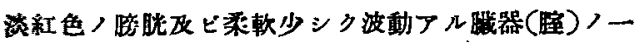

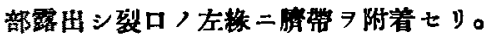

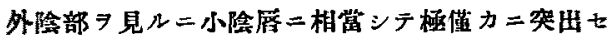
凡蒌壁アリテ其中央二小開口部アリ濑ク「ジンデ」ヨ

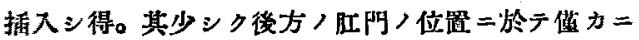
陷凹セルガ如キ所見 7 呈シ全ク等皮二被ハレテ四門 , 形成全然認 又得ズ。即于鎮朊ニシテ外性器八性別
歴然タラズ。

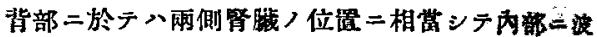

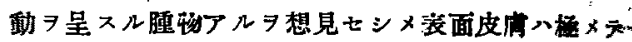
韭薄ニシテ左八籍卵大，右心胡桃大ノ大サ

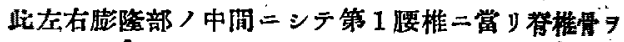
如シ陷出七ル 7 認么。外表面二於テ其他特就 キコトナシ。

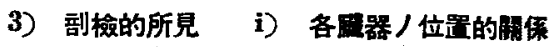

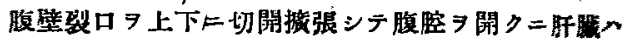

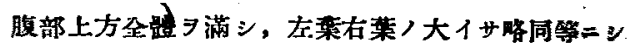

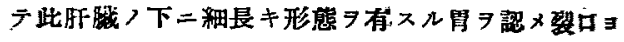

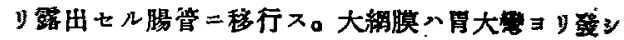
テ脾，後下方

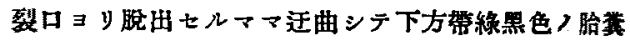

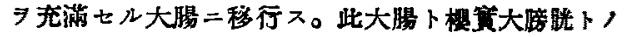

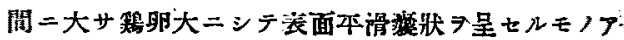

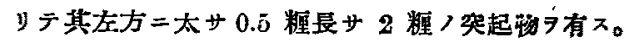
是 榆鏡所見ニテモ明ラカナル如ク眝ニシテ方方倠

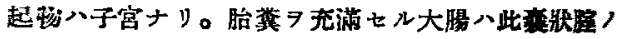

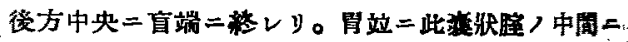

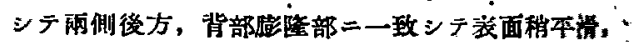

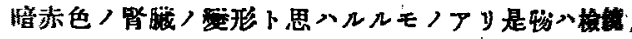

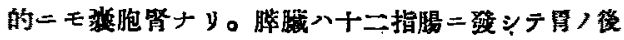

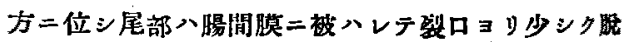

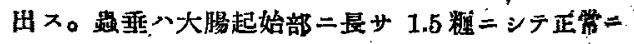

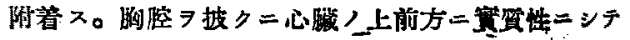

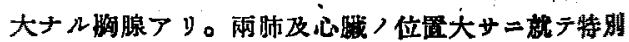

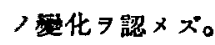

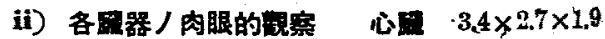

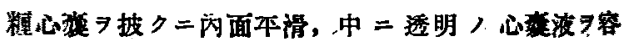

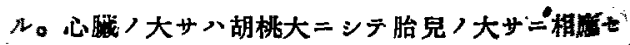

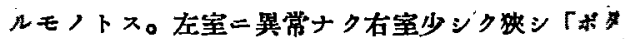

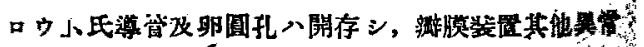

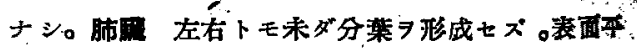

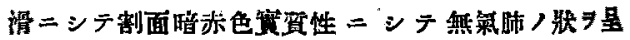

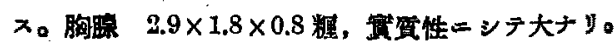

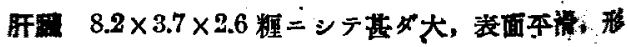




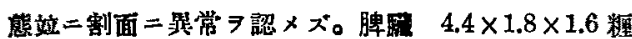
表面平滑緊淽性ニシテ少シク固ク制面暗赤色減胞著

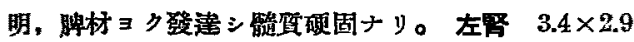

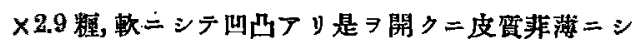

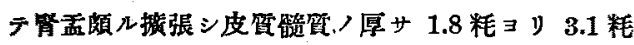

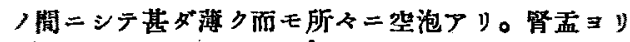

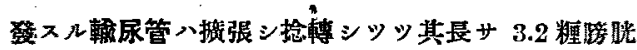
ノ左角二於テ之ト相通ズ。右堅 $4.3 \times 2.4 \times 2.0$ 㮒制

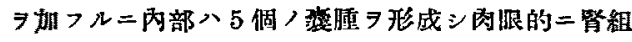

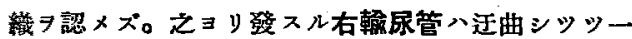

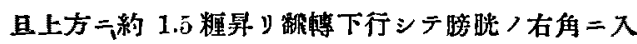
y之卜通ズ。右輸尿管ノ全長 6.1 糧。副腎 左 2.1 $\times 1.1 \times 0.8$ 右 $2.1 \times 1.4 \times 0.6$ 大二シテ雨側肾婼，上 方二位ス。膀肬 褧寅大ニシテ壁厚ク粘膜八触等二 富ミテ賠脱三角アレドモ尿道全ク缺如ス。璄及子宮

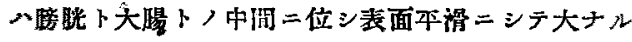

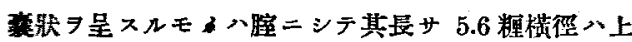

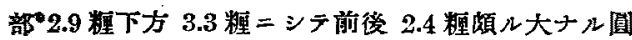
筒形

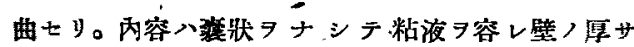

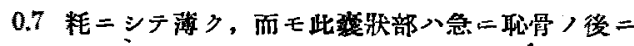

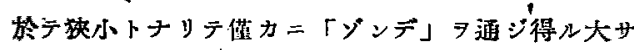
トナソテ外界二通ズ。子宮八此政狱胵，左上方二角

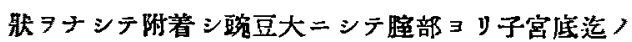

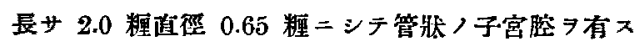

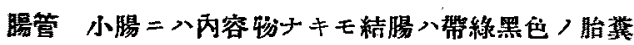
ニテ伥蔳シテ小指大ノ太サ

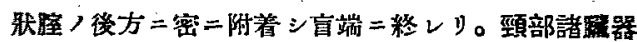

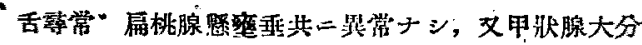

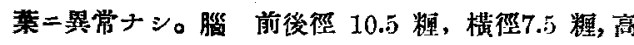

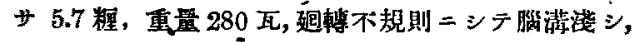

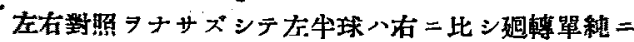

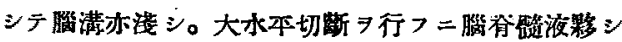

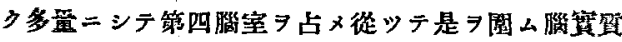

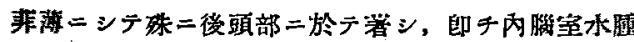

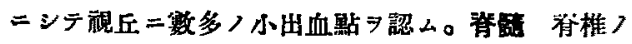

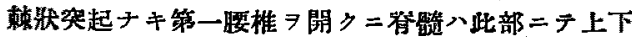

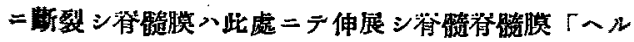

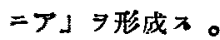

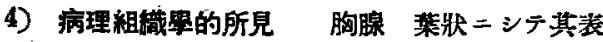

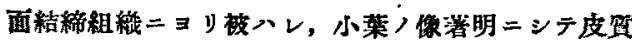

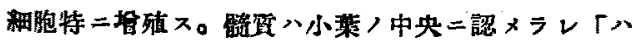

シサール」氏小顝僅カ二存在ス几モ角化像無シ。肺

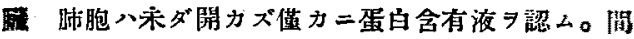

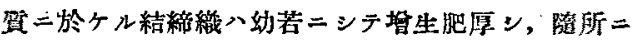

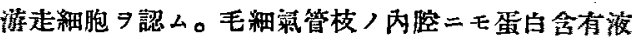

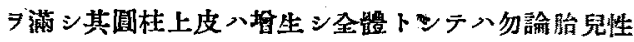

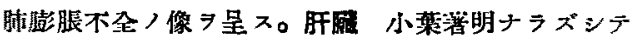

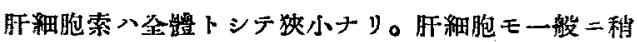

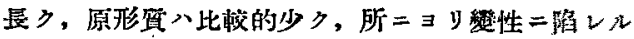
所>y。

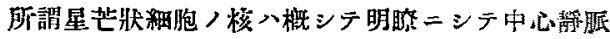

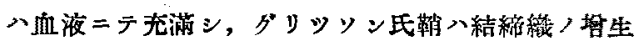

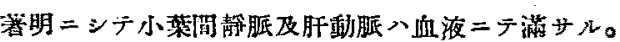

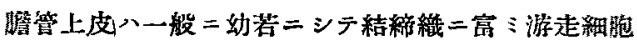

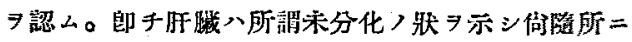

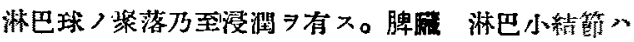

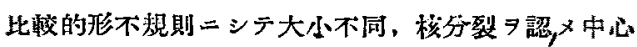

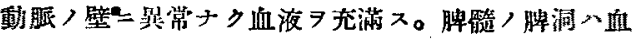

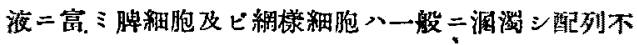

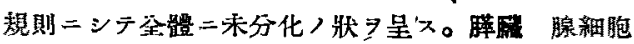
ニ「チモーゲン」顆粒ヨ認メズ间筫〉血管、血液二富

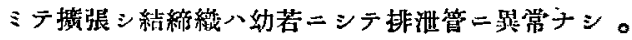

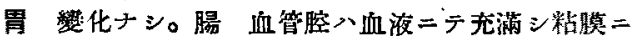

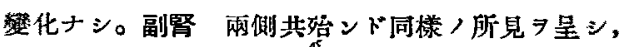
闻質, 發育良好ニシテ肥大堆殖，像

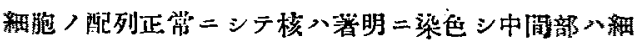

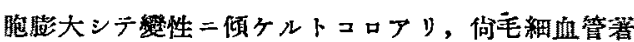

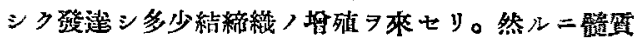

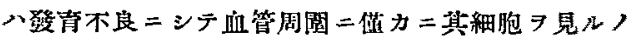

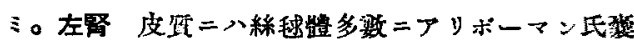
，上皮 八立方上皮ニシテ曲細尿管八年分化 7 示シ， 且初冴ナレドモ科完成せル形態

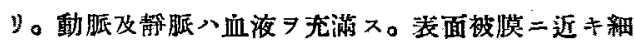

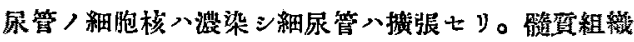
ノ登青極メテ不良ナレドモ集合管，發青八秺良好ナ

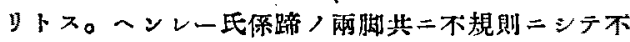

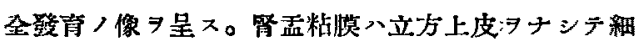

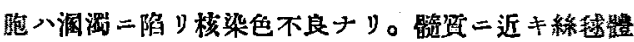

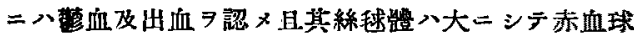

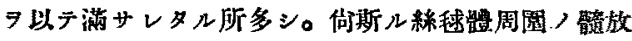

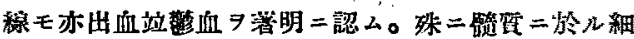

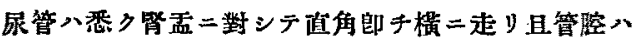

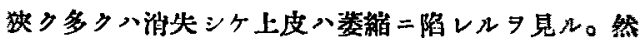




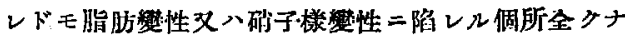

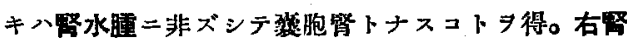

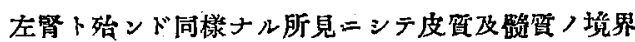
不正且所 $=$ ヨy不明二シテ被䐎二近ク未分化ノ絲铺

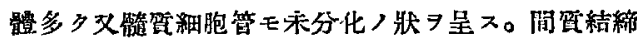

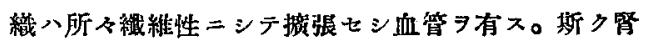

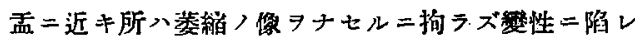

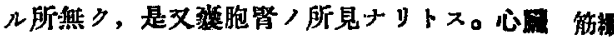

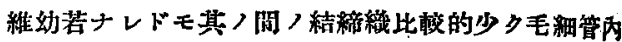

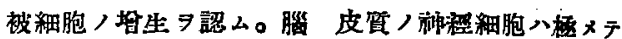

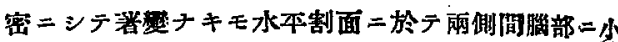
出血點 7 認 $\times$ 前頭部腿裂中二モ数多ノ小出血點アル モ組織學的二八毛細血管性出血二シテ血管入摍张シ テ血液 $\ni$ 充涩ス。

\section{第 3 章 腹壁破裂ノ交獻卜其原因二關スル鼠說站其考案}

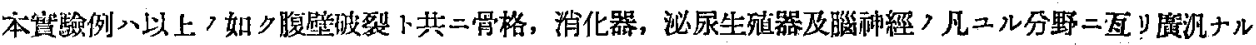

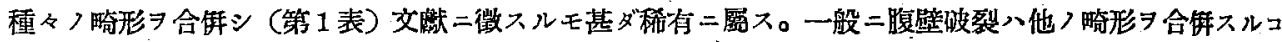

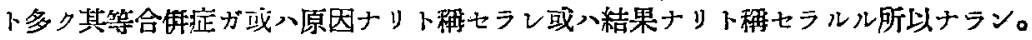

1) 腹壁破裂ノ分類：腹壁皮裂、瞕带「へルニ ア」フ高度ナルモノニシテ其「ヘルニア」翼タル羊 膜及腹膜つ忮紶七ル場合ナリトス。今日最モ一般

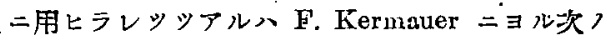
3 分類子リ。

1) Einfacher Nabelschnurbruch 單純性拐鿄 破裂 2) Angeborener Bauchbruch od, die Banchspalte 先天性腹壁破裂 B) Eventration 內臟脫出

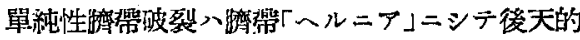
二發生スル㤯「へルニア」ガ外皮下腹膜ヨリ成ル

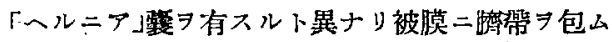
羊膜ヨ有スル點ナリ。然レドツ上 3 者习統合シ テ腹部破裂证 Ektropia viscerum 卜䊈ス。

2) 頻度: Gruber 及ビ Bloch u. Lindfoss 八 5000 间二 1 间, Martius $>3000$ 间二 1 间, Birnbaum \2000 5000 匟]= 1 国, Hyen 八

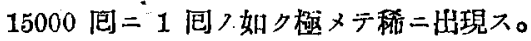

3) 脫出国器: 破裂口ヨv脫出万至八撆見七ラ

管一表 合傡セル畸形

\begin{tabular}{|c|c|}
\hline 1. 外敬上／罪常 & $\begin{array}{l}\text { 1.·腹壁破裂 } \\
\text { 2. 合指趾症 }\end{array}$ \\
\hline 2. 骨格 & 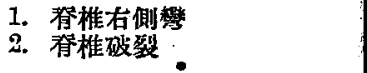 \\
\hline 3. 消化器 & 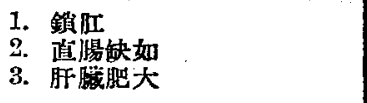 \\
\hline 4. 汹尿器 & 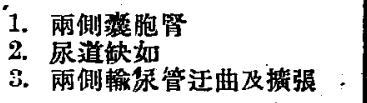 \\
\hline 5. 生殖器 & 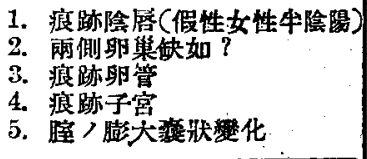 \\
\hline 6. 豚神濹 & 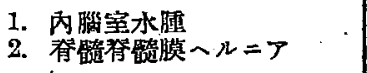 \\
\hline 7. 胎兒附䗗物 & 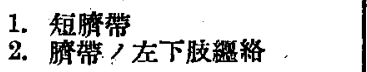 \\
\hline
\end{tabular}

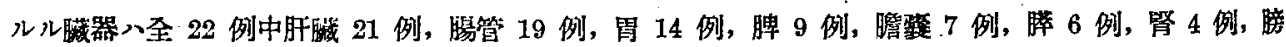

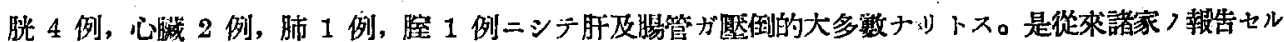
結果卜全ク一致シ Tribkait，77 例中肝 55 例, 腸 62 例, Hertzfeld 八16 例中肝 13 例, 腸 12 例二 シテ腸二次イデ八胃及脾稍多ク Thörner ハ13 例中肝 11 例, 胃 10 例ニシテ Kraemer ハ29例中訮22

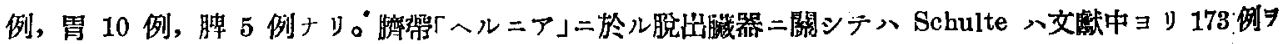

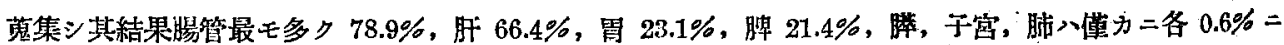
過ギズ。余フ例二於ルガ如キ㜔及膀胱ガ脫出スルガ如キハ極メテ稀ニシテ高度ナルモフトス。

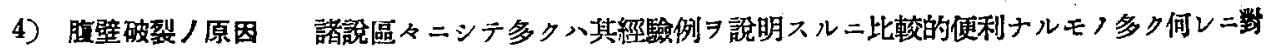

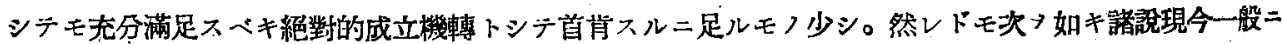

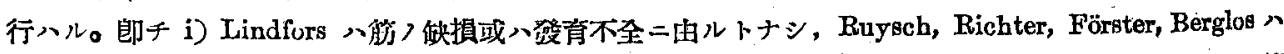
之二加フル二腹壁皮原／原腹性缺損二由ルトナセり。Kraemer, Ahlfeld 及ビ Martius モ生理的發青! 抑

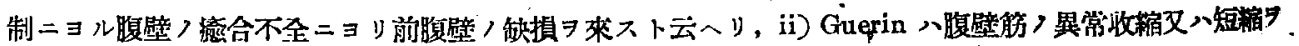




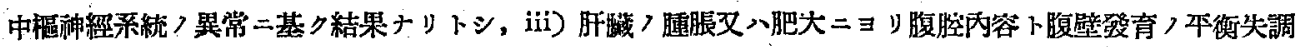

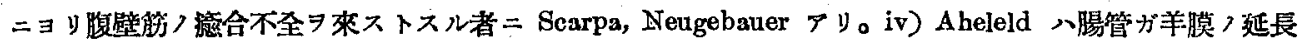

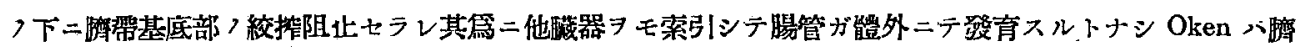

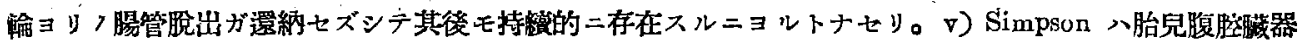

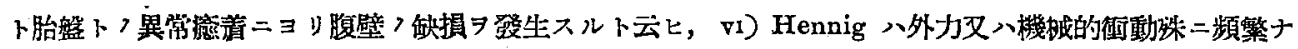

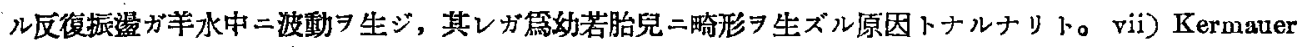
八羊膜上皮/異常分䎵ニヨリテ原發性羊膜水通

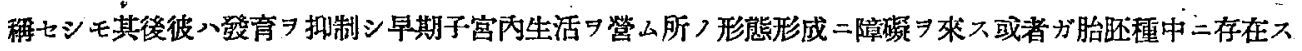

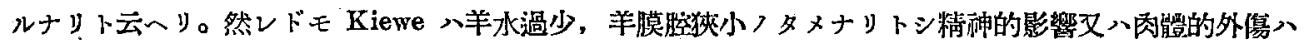

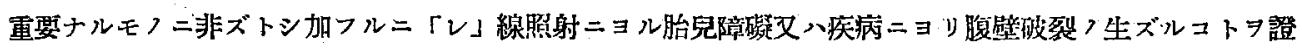

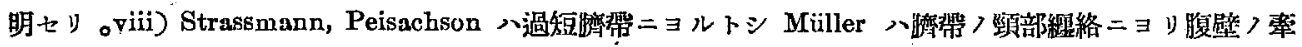

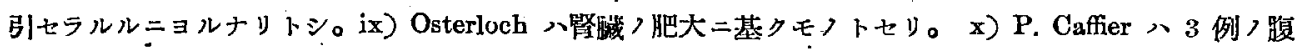

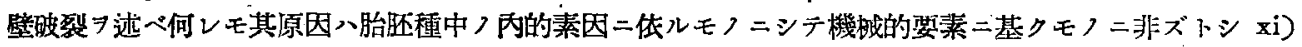
Schwalbe 八內因トシテ八心䐟疾息, 酒精中每, 微每及熱性病ニシテ外因トシテ八機械的, 精神的, 物理 化學的及ビ解剖的因于等 $习$ 列擧セリ。

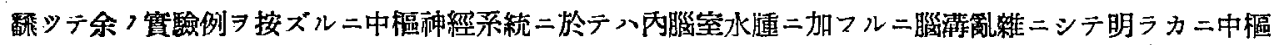

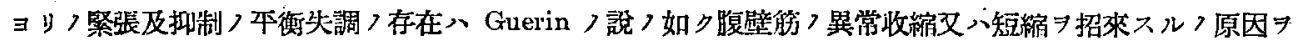

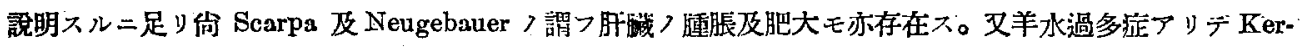

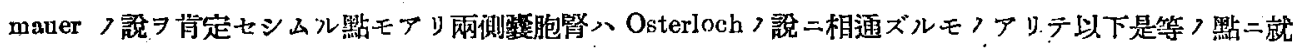
キ詩述セントス。

\section{第 4 章 驗例所見卜䐈壁破裂ノ原因二就テノ考案}

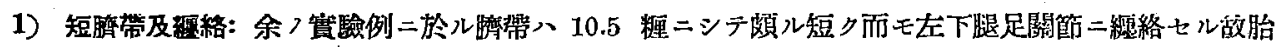

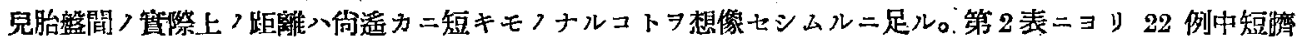

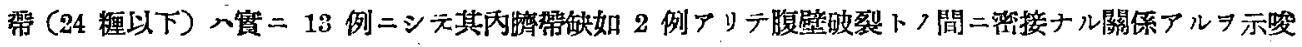

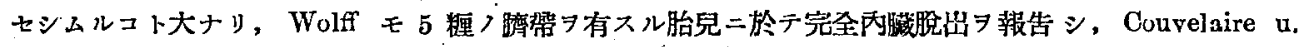

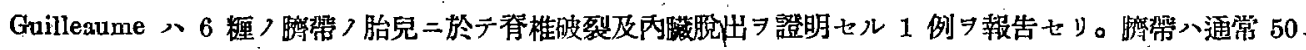

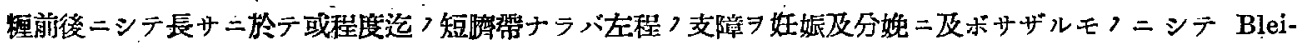

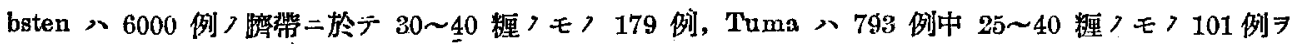
報告シ何レモ障礙ナカリキト。Sardy， München 大学ニ於ル統計ニヨレバ 20〜30 粗ノモノ八僅少ニシ

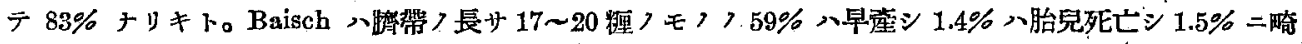

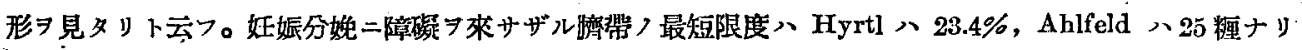

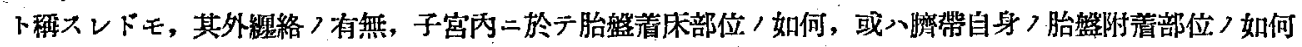
こモ左右セラルルモフナルガ敌二長サ二次イデ斯クフ如キ諸條件ヨモ考虑セザルベカラズ。历゙チ Winkel

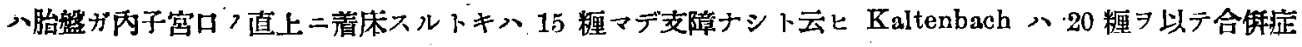

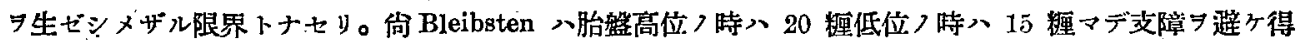

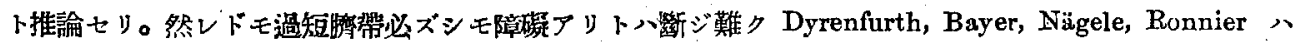

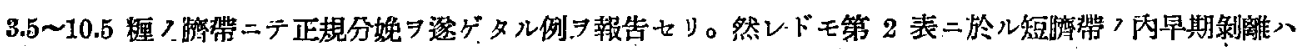

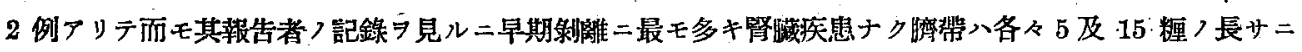

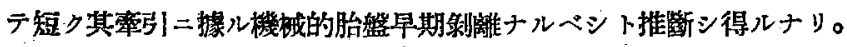

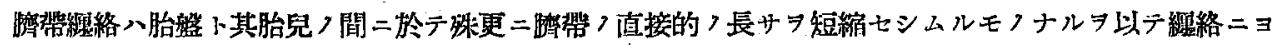

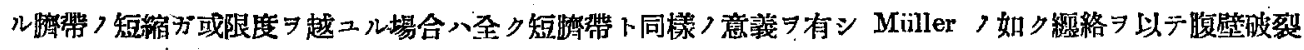
ヨ說明セントスル者アリ。 
第二表最近 7 年間腹壁碳

\begin{tabular}{|c|c|c|c|c|c|c|c|}
\hline 番躆 & 埇犮者 & 苤告年纹 & 胎龄垂吾 & 性 & 㬴 出淢 器 & 外 形 & 骨 格 \\
\hline 1 & 平暸㯲 & 昭 9 & $\begin{array}{l}4 \text { ケ月 } \\
184 \text { 瓦 }\end{array}$ & 女 & 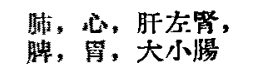 & 左上肢缺如 & 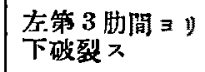 \\
\hline 2 & 数 田 & 昭 10 & $\begin{array}{l}8 \text { 午月 } \\
1600 \text { 每 }\end{array}$ & 男? & 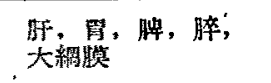 & 兩側内哠足 & 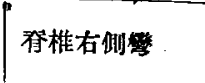 \\
\hline 3 & $\begin{array}{l}\text { 松 } \\
\text { (第一例) }\end{array}$ & 昭 10 & 8 ケ月 & 不明 & 罗，䏦，脾，愓 & & $\because$ \\
\hline 4 & $\begin{array}{lr}\text { 松 } & \text { 本 } \\
\text { (筹二侧) }\end{array}$ & 昭 15 & 5 ケ月 & 男？ & 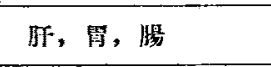 & . & 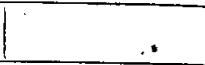 \\
\hline 5 & 㟝 東 周 & 昭 10 & $\begin{array}{l}\text { 10ケ百 } \\
2800 \text { 瓦 }\end{array}$ & & 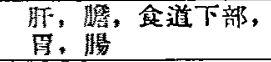 & 兩側內膰足 & 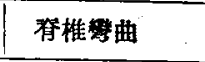 \\
\hline 6 & 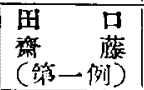 & 昭 11 & 10々月 & & 脑，量，小腸 & & \\
\hline 7 & 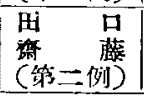 & 昭 11 & 7 ケ月 & & 肺, 胃, 脺 & & 余椎蹨曲 \\
\hline 8 & 벼 & 昭 12 & 1500 瓦 & 不明 & 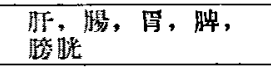 & 左下肢外踏 & , \\
\hline 9 & 弘 中 & 昭 12 & $\begin{array}{l}9 \text { ケ月 } \\
1200 \text { 畐 }\end{array}$ & & 腺，旰，睢 & & 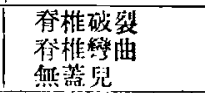 \\
\hline 10 & 矢內 原 & 昭 13 & $\begin{array}{l}7 \text { ケ月 } \\
620 \text { 瓦 }\end{array}$ & 女 & 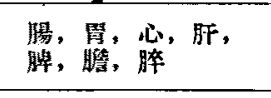 & 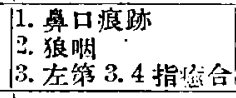 & 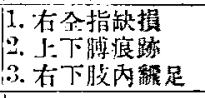 \\
\hline 11 & 井上 & 昭 13 & $\begin{array}{l}10 \text { 月 } \\
3120 \text { 瓦 }\end{array}$ & 男 & 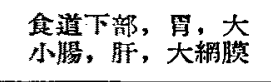 & & \\
\hline 12 & 井 上 & 昭 13 & $\begin{array}{l}10 \text { 月 } \\
2850 \text { 瓦 }\end{array}$ & 男 & 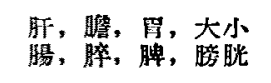 & - & \\
\hline 13 & 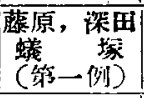 & 昭 13 & $\begin{array}{l}9 \text { ヶ月? } \\
2420 \text { 桼 }\end{array}$ & 男 & 㬴, 死 & $\begin{array}{l}\text { 內㼑足 } \\
\text { 左合趾抯 }\end{array}$ & 脊椎破裂 \\
\hline 14 & 向 & 昭 13 & 1520瓦 & 不明 & 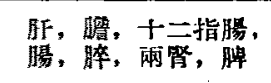 & 內絾足”. & 金棑破裂 \\
\hline 15 & 田北 & 昭 19 & & 女 & 旰, 渴 & $\begin{array}{l}\text { 1. 恨瞼附鋇 } \\
\text { 2. 鼻䔬跌如 } \\
\text { 3. 指一本 }\end{array}$ & 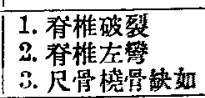 \\
\hline 16 & $\begin{array}{l}\text { 堀 汀. } \\
\text { 近 絜 }\end{array}$ & 昭 $1: 3$ & $\begin{array}{l}9 \text { ケ五 } \\
2300 \text { 瓦 }\end{array}$ & 男 & 肚, 皘, 脾, 卧 & 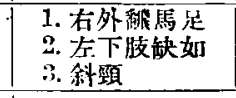 & $\begin{array}{l}\text { 脊椎破裂 } \\
\text { 忩椎䍃曲 }\end{array}$ \\
\hline 17 & 熊 㗪 & 昭 13 & & & & $\begin{array}{l}\text { 1. 整部腫瘤 } \\
\text { 2. 外魏足 }\end{array}$ & . \\
\hline 18 & ois & 昭 14 & $\begin{array}{l}9 \text { ケ月 } \\
1700 \text { 互 }\end{array}$ & 女 & 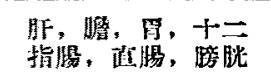 & 雨側丙䧽足 & 脊椎破裂 \\
\hline 19 & 田 & 昭 15 & $\begin{array}{l}6 \text { ケ月 } \\
350 \text { 瓦 }\end{array}$ & 男? & “腈，㧞，腎 & $\begin{array}{l}\text { 1. 上胶內和 } \\
\text { 2. 右下肢缺如 }\end{array}$ & \\
\hline 20 & 大 內 & 昭 15 & 7 ケ月 & & 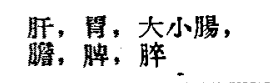 & 雨側內釈足 & 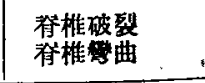 \\
\hline 21 & 多 & 昭 15 & $\begin{array}{l}9 \text { ケ月 } \\
1200 \text { 瓦 }\end{array}$ & 不明 & 脏, 舅, 腸 & 䗱合脚 & 春椎破裂 \\
\hline 22 & 箬 者 & 昭 16 & $\begin{array}{l}9 ヶ \text { 月 } \\
1420 \text { 瓦 }\end{array}$ & 女 & 大小腈, 朋, 脾, 腟 & 合指趾症 & 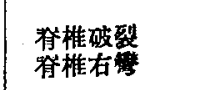 \\
\hline
\end{tabular}




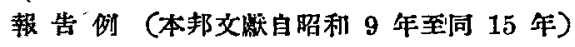

\begin{tabular}{|c|c|c|c|c|c|c|}
\hline 消 化 器 & 呼 吸 器 & 泌 尿 器 & 生 殖 器 & 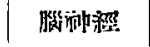 & 塍帶 & 䚚 考 \\
\hline$\because$ & . & & & & & 脑腹皏 \\
\hline 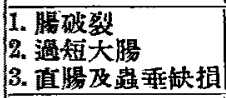 & 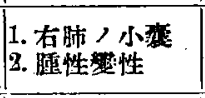 & 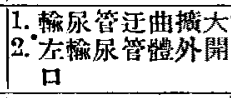 & 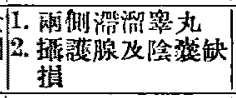 & 1. 嬥听性䏑 & 過短 & 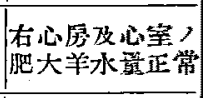 \\
\hline 領怔 & & & 外性器閏鎮 & & 缺如 & 羊水過 \\
\hline & 楎陑膜缺如 & & & & 觖如 & 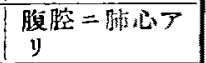 \\
\hline 肝禁ジン & & & & & 24 粧 & \\
\hline$\cdot$ & & & & & & \\
\hline & · & $\therefore$ & & & & $\begin{array}{l}\text { 前䍜胎整 } \\
\text { 帝王切留 }\end{array}$ \\
\hline 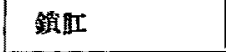 & - & & & & & \\
\hline & & & & 無蓋 & & 羊水過多狂 \\
\hline & 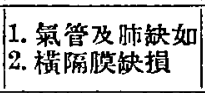 & 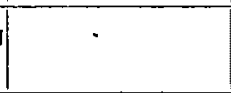 & 双角子窝 & 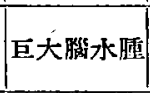 & 1S糎 & 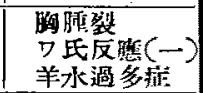 \\
\hline \multicolumn{3}{|c|}{ 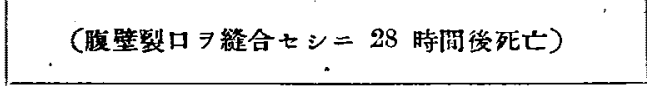 } & & & 70 米座 & $\begin{array}{l}\text { 妪娠管 } \\
\text { 兰水量正第 }\end{array}$ \\
\hline \multicolumn{3}{|c|}{ (腸管)整復不能ニシテ 39 時間後死し) } & & & 50 粴 & 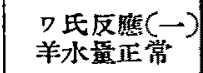 \\
\hline 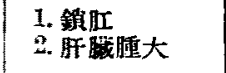 & 郴莱晎常 & $\begin{array}{l}\text { 1. 尿道缺如 } \\
\text { 2. 譄脂彩轉. }\end{array}$ & 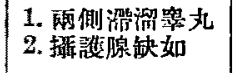 & & 48 粝 & ワ氏反跮 $(一)$ \\
\hline \multirow[t]{2}{*}{ 较胿 } & & 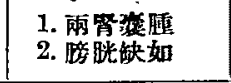 & 情器缺如 & 1 & 6 糎 & \\
\hline & & & 女性假性牛陰陽 & & 5 糎 & 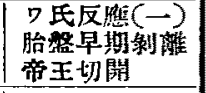 \\
\hline \multirow[t]{2}{*}{ 鎖肛 } & $\cdot$ & 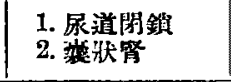 & 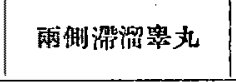 & . & 仭如 & ワ氏反然 $($ - \\
\hline & & . & & & 過短 & 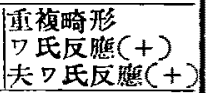 \\
\hline \multirow[t]{3}{*}{$\begin{array}{l}\text { 1. 鑚胡 } \\
\text { 2. 轮缺如 }\end{array}$} & $\begin{array}{l}\text { 1. 右肺小 } \\
\text { 2. 左肺缺如 }\end{array}$ & 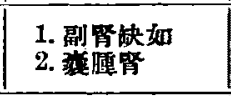 & $\begin{array}{l}\text { 1. 重䄍子富 } \\
\text { 2. 舵缺如 }\end{array}$ & & 15 糧 & $\begin{array}{l}\text { 1. 胸腹祭 } \\
\text { 2. 胎盤早則制離 } \\
\text { 3. 羊水過多 }\end{array}$ \\
\hline & & 、 & & 胘水腫 & & ワ氏反雕 $(一)$ \\
\hline & & & - & & 14.4 湅 & $\begin{array}{l}\text { 羊水少量 } \\
\text { (400ec) }\end{array}$ \\
\hline $\begin{array}{l}\text { 1.賽䏠 } \\
\text { 2. 阼著シク大 }\end{array}$ & & 尿道改脖脱钭如 & 内外生殖器缺如 & & 23 糢 & ワ氏反胎 $($ - $)$ \\
\hline 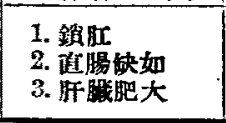 & - & 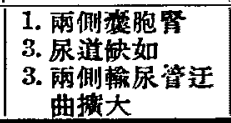 & 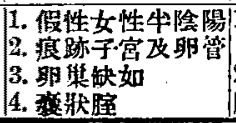 & 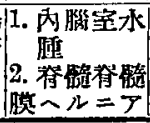 & $\begin{array}{c}10.5 \\
\text { 程絡 }\end{array}$ & $\begin{array}{l}\text { ワ氏反僬 }(一) \\
\text { 妊娠督 }\end{array}$ \\
\hline
\end{tabular}




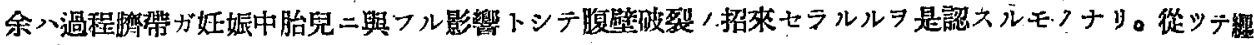
絡モ亦或場合八其原因タル得ルモノ卜思惟スルモフナリ。

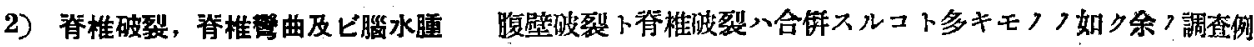
ニ於テモ 22 例中 10 例ノ脊椎破裂ヨ見タリGruber及ビ Griesbeck モ殆ンド常二合伤スト程スレドモ䧗

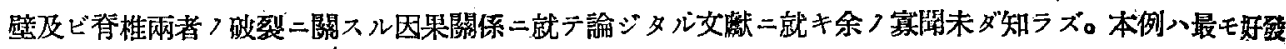

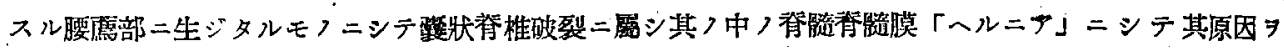

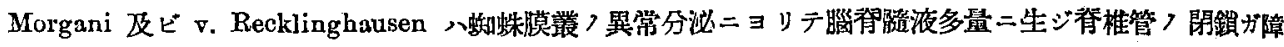

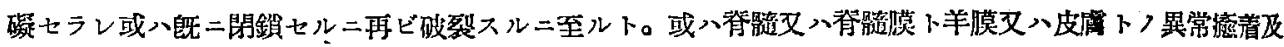

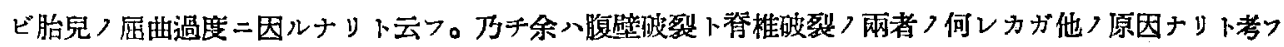

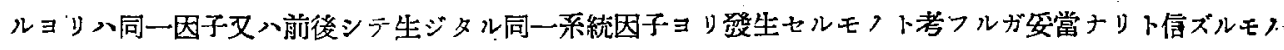
ナリ。

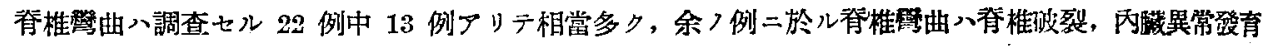

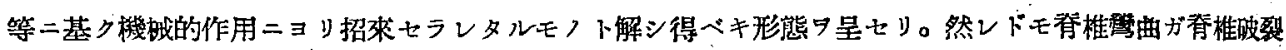

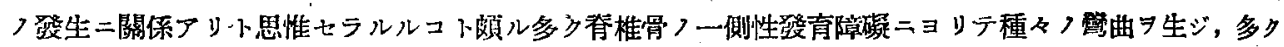

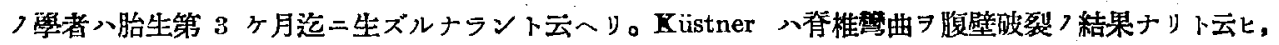
Hohl u. Cruveilhier 八逆二其原因ナリト稱スルモ Peisachson, Gruber 八多クハ脊椎側方又ハ後慜シ其 部 >硬腦膜候如スト云〉。

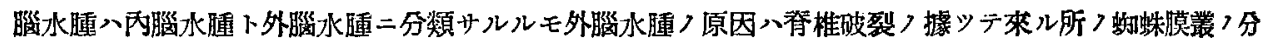

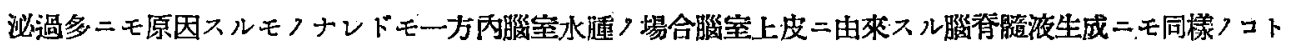

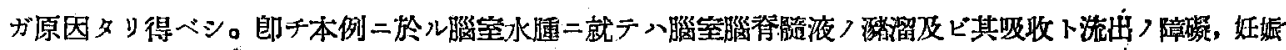

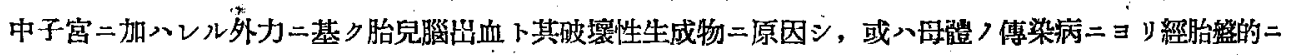

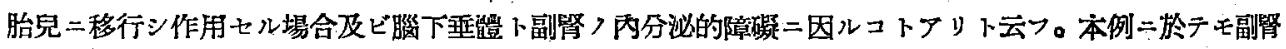
皮質 フ肥原增生著明ニシテ其內分泌的異常ニ據ルコト無キニシモ非ズト思惟セラル。

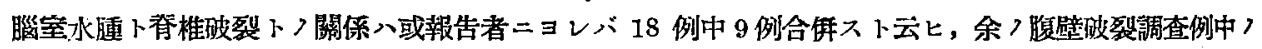
脊椎破裂例 10 例二八腦水腫入余，例

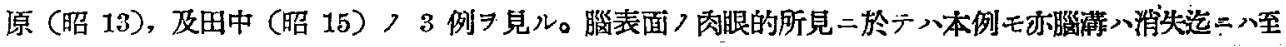

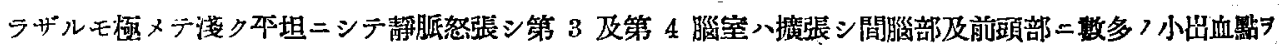

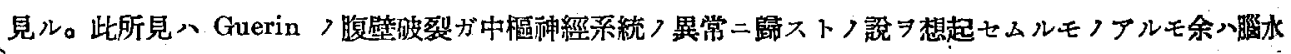

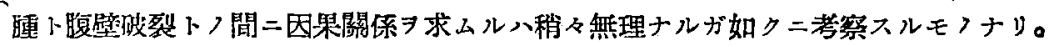

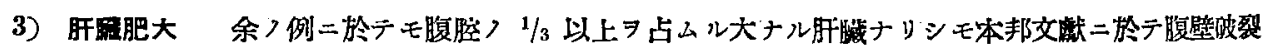
トフ關係ニツキ詳述セルモノ少ク，余フ腹壁破裂調查例 22 例中郭, 藤原, 深田, 蟻塚ノ第1 例及ビ本多

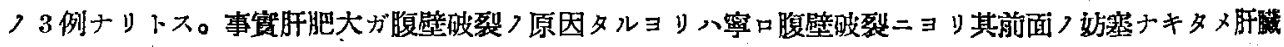

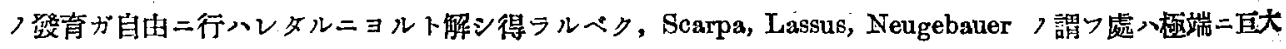
ナル肝睛ニテ腹壁习破綻セズニハオカザル程ノ場合ナラバ首肯シ得ル處ナリ。

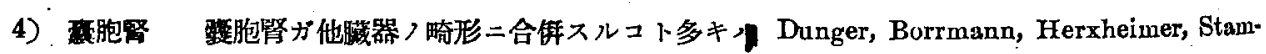

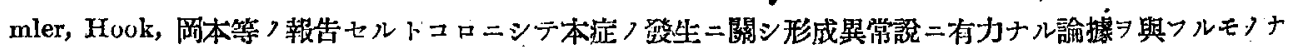

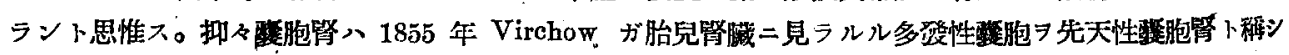

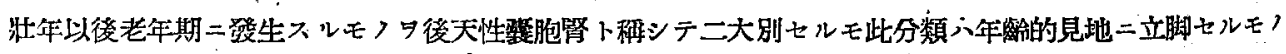

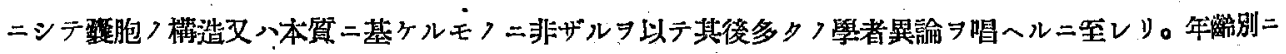

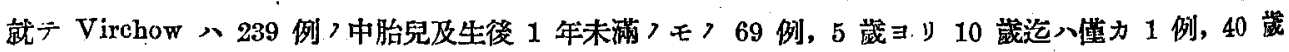

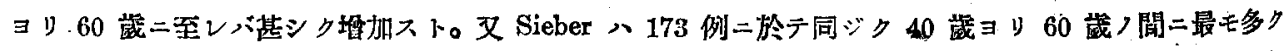
80 歳以後二僅カ 2 例 7 認メタリト云つ。 


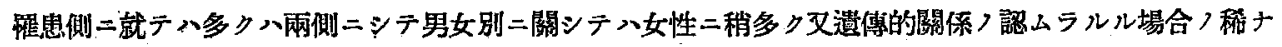

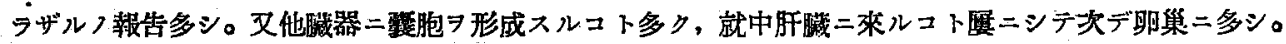

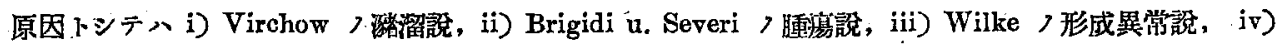

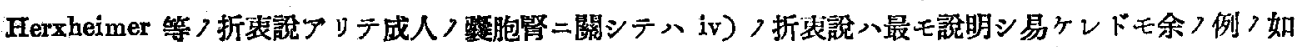

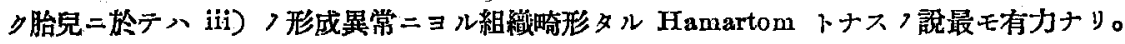

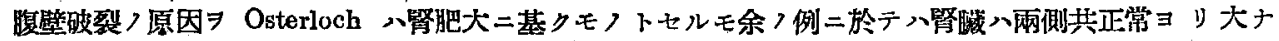
ルモ腹壁破裂二至ル程大ナラズト思考ス。

5) 羊水過多店 本例二於テ八羊水 $1800 \mathrm{cc}=シ テ$ 甚シク八多量ナラザルモ胎兒重量 1420 瓦妊娠 9 ケ月トシテ 八生理的限界シ超過セルモフト云フベク，余〉調查セル腹壁破裂 22 例中羊水過多〉記載アル

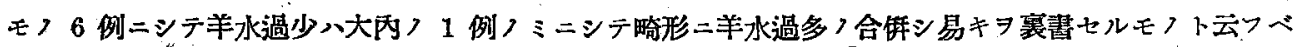

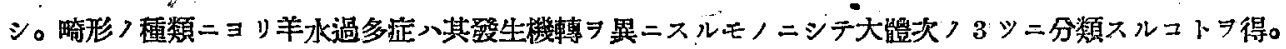

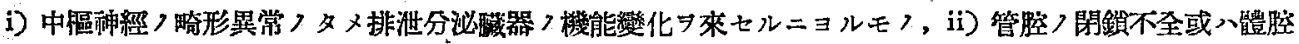

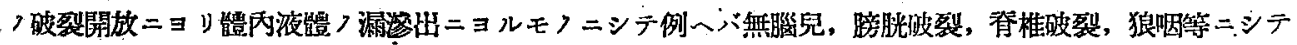

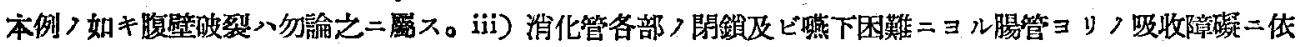

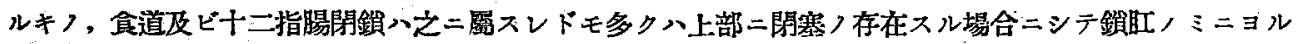
羊水過多入蓝シ稀ニシテ本例入寧口羊水過多フ主原因ヨ腹壁破裂二歸スコトラ得。

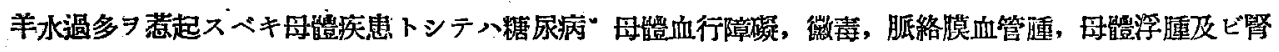
疾患つ場合ニシテ, 本例八當時母體二浮腫全身二來り，尿中蛋白中等度陽性ニシテ盟ラカ二壟液排洲機能

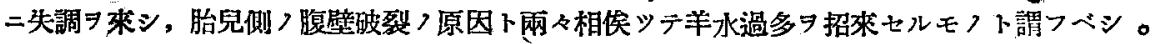

\section{第 5 章 女性假性半陰陽}

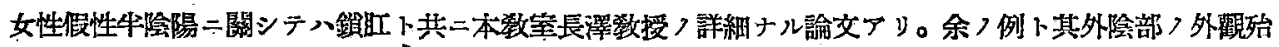

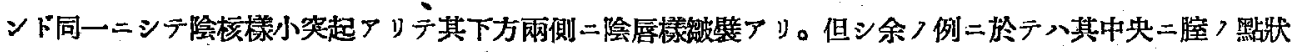

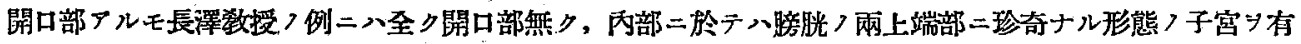

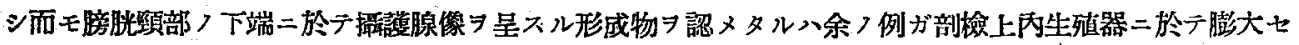

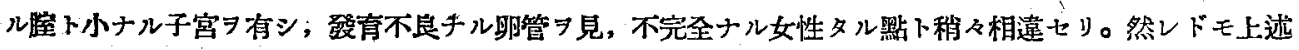

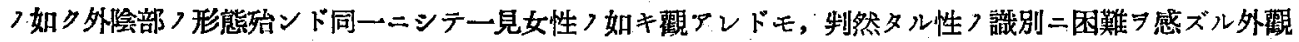

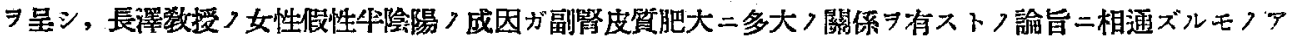
ルフ以ラ以下是二就キ諭ゼントス。

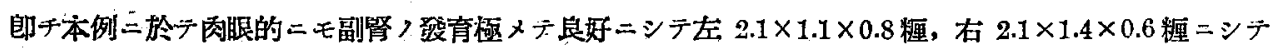

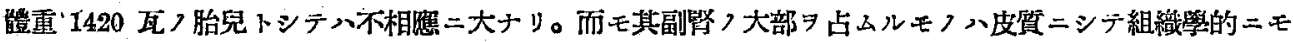

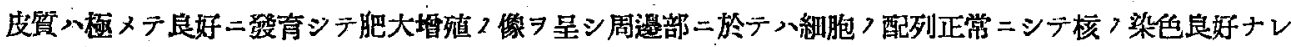

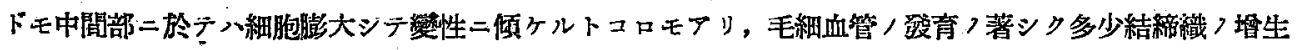

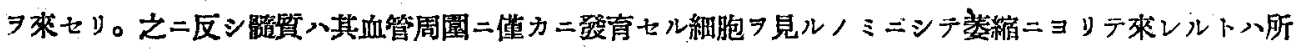

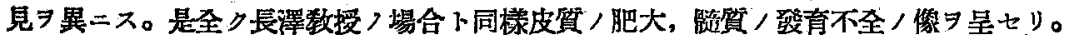

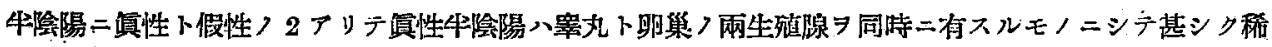

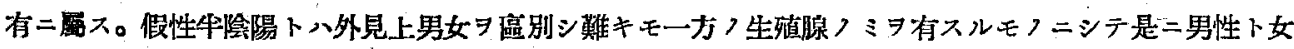

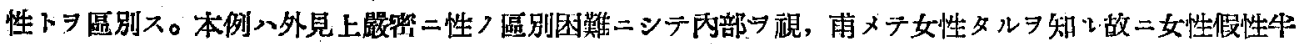

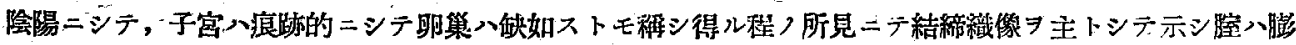

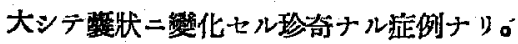

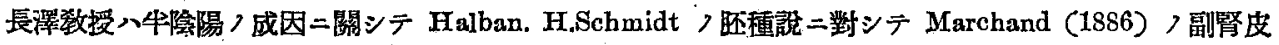

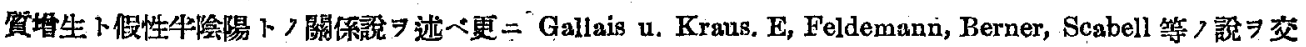

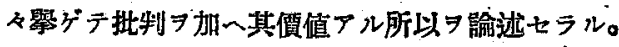


最近成人牛陰陽 /與味厂ル症例トシテ

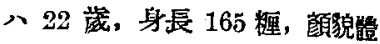

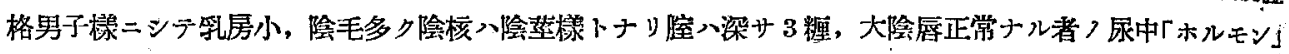
ア1ケ月二互り定量セルニ向性腺「ホルモン」ハ少ク畉胞「ホルモン」入㙁加シ，且男性「ホルモン」モ亦

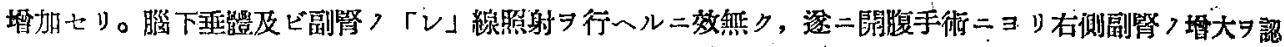

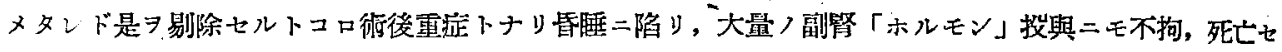

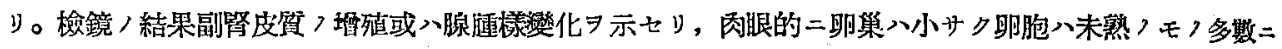

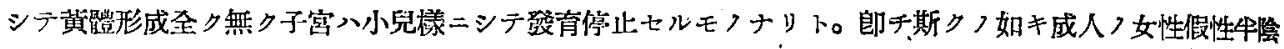
陽二徽スルモ副腎皮貿つ增大ガ重要ナル因子ヨ第スモつ下謂フベシ。

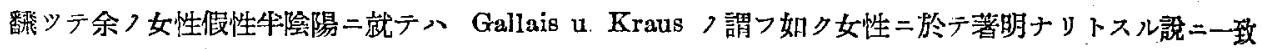

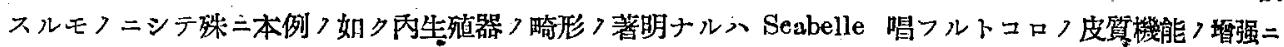

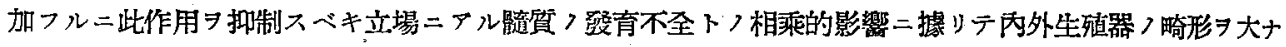
ラシメタルモフト思考シ得ラルルナリ。

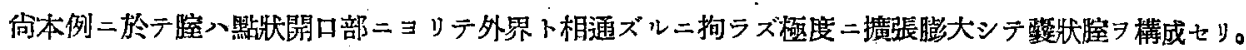

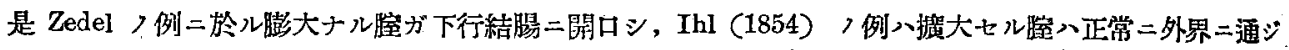

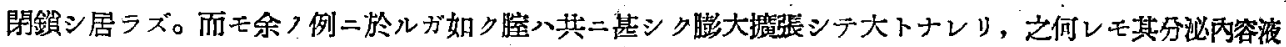

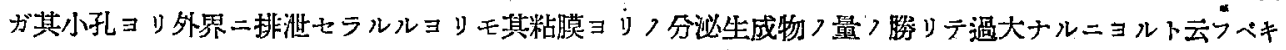
力。

\section{第 6 章 最近ノ一般畸形發生論}

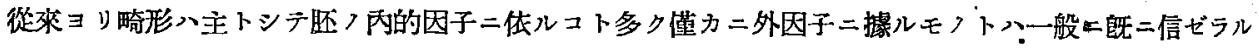

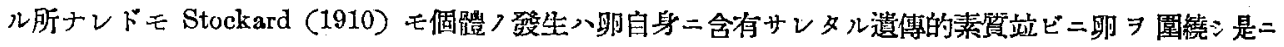
作用スル外的要約ノ交互作用二制約七ラルルトナシ，先天的畸形八-般二頲傳サルルモ又一方二於テ服？ 外的要約二传儿影響フ下二發生ス卜考へラル。偶發的畸形ガ如何ナル原因二㨜ルカ未ダ明ラカナラズ。

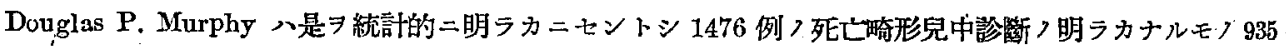

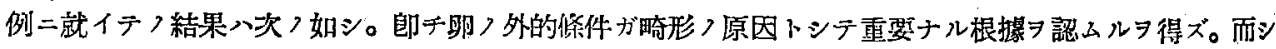

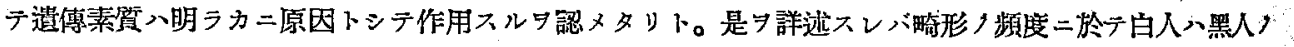

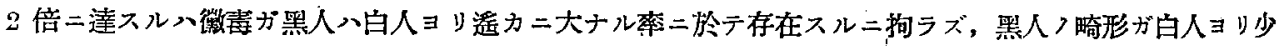

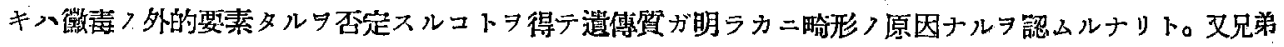
姉妹二渏形ガ反復スルコト殊二最モ稀有ナル重症畸形ガ反復スル事實二䫑ハレ得ルハ有力ナル遺傳說习支

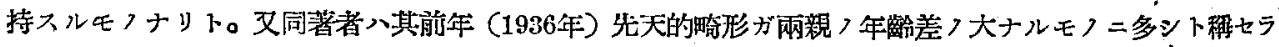

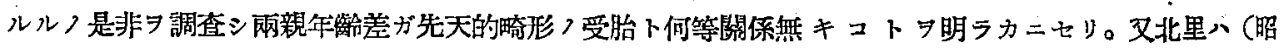

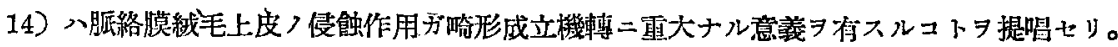

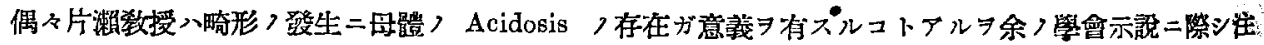

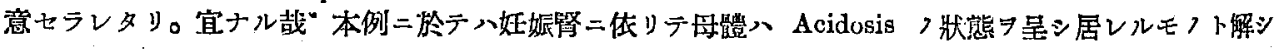

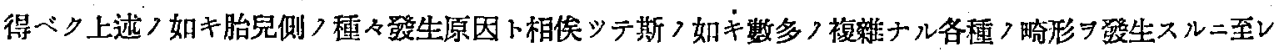
ルモノト解シ得ベシ。

\section{第 7 章 結諭}

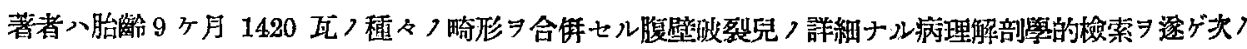
如キ諾點フ認メタリ。

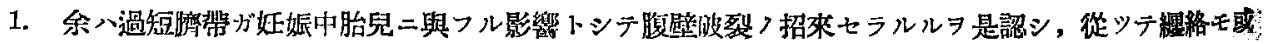
埸合二八其原因タリ得ルモつ卜思惟ス。

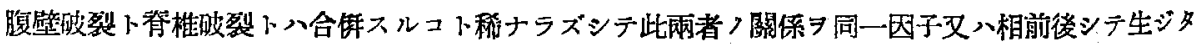

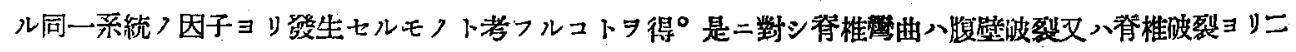


灰的二生ジタルモノ下見做シ得。

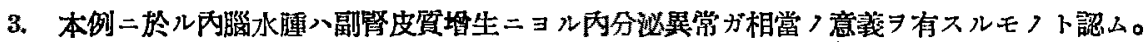

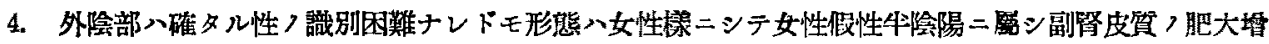

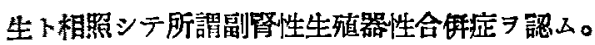

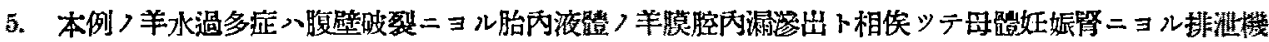
能不至二依ルモ〉思考不。

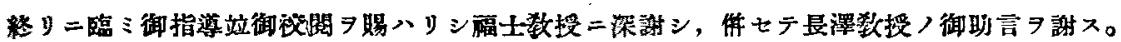

$$
\text { 文 }
$$

1) Kermauer: Halban-Seitz Biologie u. Pathologie des Weibes B. 3. S. 529, 1924.

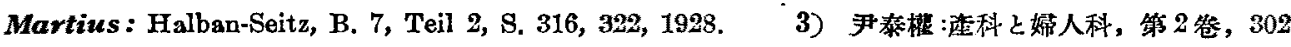

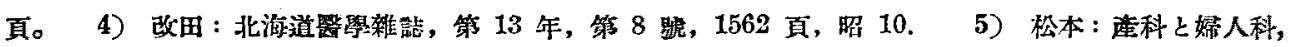

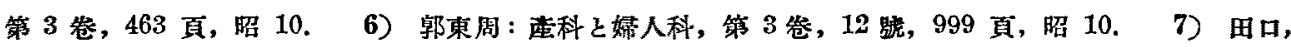

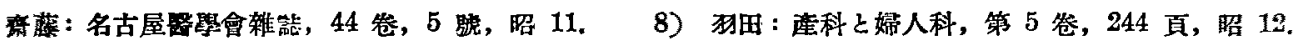

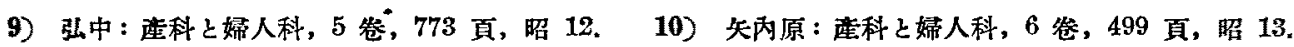

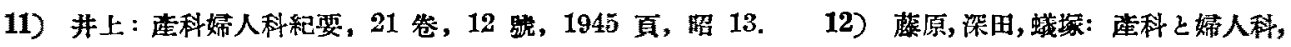

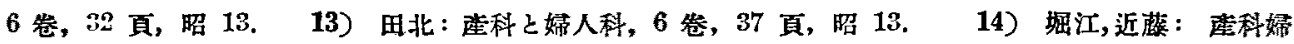

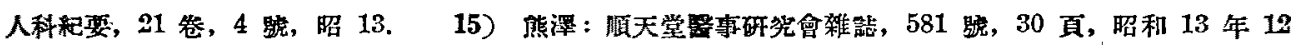

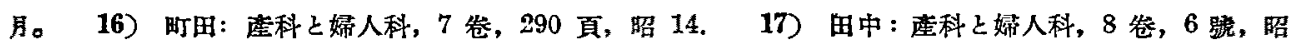

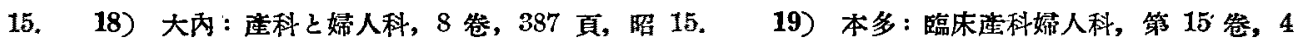

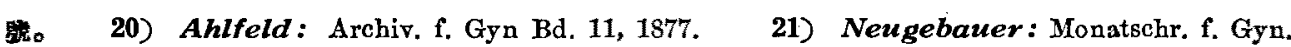
Bd. 20, S. 1919, 1904. 22) Kermauer: Arch. f. Gyn. Bd. 78. S. 221, 1906. 23) Peisachson: Monotschr, f. Gèb. u. Gyn. Bd. 88, 1931. 24) Caffier: Zbl. f. Gyn. s. 1103. 1933 25) Schwalbe: Die Morphologie der Missbildungen des Meuschen und der Tiere Teil 3. 1909. 26) Walf: Arch. f. Gyn. Bd. 57. S. 635, 1899. 27) Baisch : Döderleins Fandbuch d. Gyn. III.

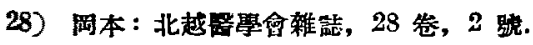

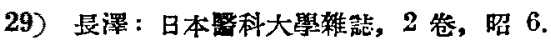

Feldmann: Virch. arch. Bd 259. 1926.

31) Scabell : Dtsch. Zeitschr. f. chir. 1924.

Schmidt: Virch. Arch. Bd. 251. 1924. 33 Z Zedel: Zeitschi, f. Geb. u. Gyn. Bd. 32. H. 2. 34) Ihl : Zeitschr. f. Geb. u. Gyn. Bd. 6. 1854. Z. nach Schwalbes Mißlildungez des Menschen. 35) Douglas P. Murphy : Americ. J. obst. a. Gynec. Bd. 32, P. 873 1936. Am. J. Obst. a. Gyn. Bd 34, 1937. 36) 北里：長﨑醫學會雜誌, 17 卷, 1571 頁, 昭 $14 . \quad 37)$ Charvat, Kodicek.

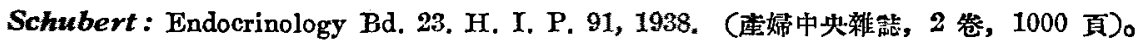

